\title{
Proceeding
}

Supplementary Issue: Rio 2016 Olympic Games First Anniversary Special Edition. Olympic Studies Forum, 4-5 August 2017. Santa Úrsula University. Rio de Janeiro, Brazil

\section{Rio 2016 Olympics: Urban regeneration and social legacy}

\begin{abstract}
SILVESTRE CIRILO DOS SANTOS NETO1 1 , VINICIUS DENARDIN CARDOSO², THIAGO SANTOS ${ }^{3}$, AILTON FERNANDO SANTANA DE OLIVEIRA ${ }^{4}$, DENIS ROBERTO TEREZANI ${ }^{5}$, MARCELO DE CASTRO HAIACHI ${ }^{4}$
\end{abstract}

${ }^{1}$ Olympic Studies Centre, Rio de Janeiro State University, Brazil

${ }^{2}$ Department of Physical Education, Roraima State University, Brazil

${ }^{3}$ Post-Graduate in Physical Education Programme, Parana Federal University, Brazil

${ }^{4}$ Department of Physical Education, Sergipe Federal University, Brazil

${ }^{5}$ Brazilian Confederation of Canoeing, Brazil

\begin{abstract}
This study aimed to analyse the changes occurred in the urban space in the city of Rio de Janeiro face the Rio 2016 Games. In order to achieve this goal, official documents (bid, the organizing committee, and the legacy plan), official websites and newspapers websites with national and international coverage were analysed. This revealed the Olympic Games worked as catalyser to urban regeneration, mainly in "Porto Maravilha" and the surrounding area to Deodoro X-Park and, the great expansion to transport system, improving the urban mobility, linking all the Rio de Janeiro regions. Consequently, the social legacy appeared mainly in the Deodoro X-Park area, where there was no leisure in public area. Moreover, through improvements made in mobility brought another social aspect linked to the Games. Thus, it is true that the Olympics works as a catalyser to urban space, but not always it is happening in a meaningful, depending exclusively on own governments and a realistic planning for the city. Key words: OLYMPIC GAMES, LEGACY, CLUSTER, DEODORO, MARACANÃ, COPACABANA, BARRA, OLYMPIC PARK, RIO 2016.
\end{abstract}

\section{Cite this article as:}

Santos Neto, S.C., Cardoso, V.D., Santos, T., Oliveira, A.F.S., Terezani, D.R. \& Haiachi, M.C. (2018). Rio 2016 Olympics: Urban regeneration and social legacy. Journal of Human Sport and Exercise, 13(1proc), S116-S133. doi:https://doi.org/10.14198/hihse.2018.13.Proc1.10

Corresponding author. Olympic Studies Centre, Rio de Janeiro State University, Brasil. http://orcid.org/0000-0001-8628-9308 E-mail: silvestrecirilo@yahoo.com.br

Supplementary Issue: Rio 2016 Olympic Games First Anniversary Special Edition. Olympic Studies Forum, 4-5 August 2017. Santa Úrsula University. Rio de Janeiro, Brazil.

JOURNAL OF HUMAN SPORT \& EXERCISE ISSN 1988-5202

(c) Faculty of Education. University of Alicante

doi:10.14198/jhse.2018.13.Proc1.10 


\section{Jogos Olímpicos Rio 2016: Regeneração urbana e legado social}

\section{RESUMO}

Este estudo teve como objetivo analisar as mudanças ocorridas no espaço urbano da cidade do Rio de Janeiro face aos Jogos Rio 2016. Para atingir esse objetivo, foram analisados documentos oficiais (proposta, o comitê organizador e o plano de legado), sites oficiais e sites de jornais com cobertura nacional e internacional. Esta análise revelou que os Jogos Olímpicos funcionaram como catalisador da regeneração urbana, principalmente no "Porto Maravilha" e na área circundante para o Parque Radical, em Deodoro, somado a grande expansão do sistema de transportes da cidade, melhorando a mobilidade urbana e, ligando todas as regiões do Rio de Janeiro. Consequentemente, o legado social apareceu, principalmente, na área do Parque Radical, onde não havia equipamentos voltados ao lazer da população local. Além disso, as melhorias observadas na mobilidade urbana trouxeram outro aspecto social vinculado aos Jogos. Assim, é verdade que os Jogos Olímpicos funcionam como um catalisador para o espaço urbano, mas nem sempre isto acontece de maneira significativa, dependendo exclusivamente de seus próprios governos e um planejamento realista para a cidade. Palavras-chave: JOGOS OLÍMPICOS, LEGADO, CLUSTER, DEODORO, MARACANÃ, COPACABANA, BARRA, PARQUE OLÍMPICO, RIO 2016. 


\section{INTRODUCTION}

The different ways of planning a city differ according to the environment in which they are inserted, being driven by factors that characterize their identity with the urban space, be they cultural and / or social. The Olympic city of Rio de Janeiro, chosen to host the world's most important multi-sport mega-event, represents an expectation of modernization and prosperity in a short space of time. Urban planning based on choice as a host city is closely related to possible social, economic, political, cultural and environmental impacts.

Coaffee (2011) argues that the importance of urban regeneration has been growing in the last 50 years, while at the same time it is a recent perception of the benefits of hosting a sports mega event, in order to promote community development and sports infrastructure. Since the Olympic Games began in 1896, standards related to the planning of host cities have been observed. Up until 1956, in Melbourne, planning was focused primarily on sports facilities. Between Tokyo in 1960 and Moscow in 1980, planning turned to investments in infrastructure for the city, especially transportation and sports facilities. Seoul in 1988 saw the Olympic Games as a catalyst for the promotion of urbanism. Barcelona, even after 25 years of the Games, is considered as the model to be followed when we talk about urban planning and the regeneration of urban space. In addition, the main investment was infrastructure, in which $87 \%$ of the budget was invested. Since 2008 in Beijing, the Games have been "sold" as catalysts for infrastructure and urban regeneration.

Thus, urban regeneration of large metropolises is anchored in the master plan that seeks to establish architectural planning, accessibility and sustainability of specific areas. Do these mega events really contribute to urban regeneration of degraded areas, with low sustainability, difficult urban mobility and access in host cities?

In this sense, the city of Rio de Janeiro was marked by the elaboration of two urban plans since the 1930s that are constantly cited: Agache and Doxiadis Plan. Rezende (2014), discussing both plans, describes the plan "City of Rio de Janeiro, remodeling, extension and embellishment" that was designed by Donat-Alfred Agache between 1927 and 1930, presenting a pattern established at the time: a plan with physical-territorial aspects with a social approach. According to Abreu (1997, p.86), the Agache Plan aimed to "order and improve the city according to functional criteria of social stratification of space", turning mainly to the regions of the Center and South Zone. However, as reported by Andreatta (2006), this plan was never officially approved, but had its piece used in the Pilot Plan of the city between 1938 and 1948.

Then, with the change of the federal capital to Brasilia in 1960, the Federal District was transformed into the State of Guanabara, and the then governor Carlos Lacerda commissioned the plan "Guanabara, a plan for urban development" in 1964, also, like Doxiadis Plan. However, at the end of the Lacerda's administration, there was neither time nor resource for implementing the plan (Mello, 2012).

Despite that, Rodrigues and Mello (2015) report that the Doxiadis Plan has never been totally abandoned, serving as a subsidy for future planning involving the urbanization of Rio de Janeiro. In 1971, the Department of Roads and Roadways (DER) announced the Plan of the Polychromic lines, which would integrate the regions of the city cut by the Tijuca and Pedra Branca massifs. However, it was only in the 1990s that the red and yellow lines were built together with a section of the green line made in 1972. In 1977, the Basic Urban Plan (PUB Rio) and the Transport Integration Plan (PIT) were presented as a framework, while looking at the city as a whole, but focused on the transport system. In 1993, the City of Rio de Janeiro launched the strategic planning known as "Rio Sempre Rio", which included the Favela Bairro and the Rio Cidade urbanization program, with interventions in the neighborhoods of Rio de Janeiro. In 2004, the strategic 
planning "As Cidades da Cidade", known for dividing the city into twelve macrozones, treating the city as isolated regions and adopting equipment away from the street (Cidade do Samba - Gamboa, Cidade da Música - Barra da Tijuca, Cidade das Crianças - Santa Cruz). In 2009, the "Pós-2016: Rio mais integrado e competitivo" plan was submitted, updated in 2013, and aimed at the internationalisation of the city, with a catalyst for electing the city to host the Olympic and Paralympic Games in 2016, he launches a plan to revitalize the port area - Porto Maravilha (Saúde, Gamboa, Santo Cristo, São Cristóvão and Centro) with the intention of expanding to the whole city afterwards.

After this brief explanation about how the city of Rio de Janeiro has dealt with urban regeneration over the years, it is understandable the expectations of the population in relation to the improvement in the urban infrastructure of the city - airports, highways, port, rail transportation, public transport system and transit management (Burbank, Andronovich, \& Heying, 2002). Specifically in the case of the city of Rio de Janeiro, it is estimated that 6.4 million inhabitants are distributed over an area of 1.2 million square kilometers (IBGE, 2012). With the progressive increase in the number of inhabitants, estimated at $10.3 \%$ per year, associated with the lack of urban planning to facilitate its locomotion, it generates constant disturbances in public roads, long congestion and a large accumulation of vehicles since public transport ends up being inefficient or uncomfortable to handle the high flow of people.

Besides, the social and economic impacts (the generation of employment and income, attraction of foreign capital, sports development, increase in tourism and acceleration of urban development) are mentioned by the organizers as more than positive justifications for hosting events such as the Olympic Games (Heere et al., 2013). Complementary, the addition to the Olympic Charter of the IOC's role in promoting a positive legacy of the Olympic Games for host cities and host countries ratifies the need to think of this type of event as a development opportunity for the community Reis, Sousa-Mast and Gurgel (2013). This is because a sports mega event tends to influence the quality of life of the residents (Santos et al., 2016, Taks, Chalip, \& Green, 2015). Thus, the objective of this article is to analyze the changes occurred in the urban space in the city of Rio de Janeiro face the Rio 2016 Games.

\section{MATERIAL AND METHODS}

The study is centered on the descriptive research of a qualitative approach, being configured as a study case when carrying out a detailed description and analysis of a unique phenomenon, Rio 2016 Games, when orienting itself from a deep understanding of a singular reality, urban regeneration. It should be noted that this framework was used for the special characteristics and distinct properties of this mega event and could be constituted as an "out-of-series" case (Yin, 2015).

In order to generate hypotheses, diagnose situations and produce indicators, we focus our focus on the four clusters used in the Rio 2016 Games and their respective regions, 1) Deodoro (Western Zone); 2) Barra (West Zone); 3) Maracanã (North Zone); 4) Copacabana (South Zone) plus areas of Deodoro X-Park (West Zone) and Olympic Boulevard (Central Zone).

The procedure adopted for the present case study was to consult the official documents (bid, the organizing committee and the legacy plan), official websites and newspapers websites with national and international coverage, and then carry out a critical analysis of the material lifted up. As a guiding map of this analysis, the interpretation of the material was established in three moments: a) the application period and the analysis of its proposals (2007-2009); b) the choice of the host city and the legacy plan (2009-2016); c) the delivery of a revitalized city, with better urban mobility and accessibility (2016-2018). 


\section{DISCUSSION}

\section{Urban Regeneration and the Olympic Boulevard}

The great contemporary metropolises have undergone many changes in recent decades. They transform the landscape of the big cities bringing about significant changes in the daily life of its population. These metropolises, through a process of accelerated urbanization, end up causing a state of deterioration in their territory, reducing the quality of the urban space and the quality of life of its population, these disorders, which require the eminent need for intervention.

Urban regeneration seems to be fundamental for the reversal of this scenario. Despite facing major challenges, requiring large financial investments, facing many urban problems (traffic, environmental issues, territorial expropriations, etc.), and this action will provide good opportunities for the population of the cities that choose to do so.

Roberts and Sykes (2000) define the process of urban regeneration of a city as a comprehensive and integrated vision of actions that lead to the resolution of urban problems and that seek to improve in a lasting way the economic, physical, social and environmental conditions of a subject area to changes.

In this sense, urban regeneration develops strategies and promotes a process with an inclusive and integrative character, capable of provoking initiatives, projects and actions, being an instrument for improving the living conditions of the population, building and recovering the infrastructure and, public space (Moura, Guerra, Seixas, \& Freitas., 2006).

The urban regeneration provided by the sports mega-events can be perceived through actions to build new sports structures (which are widely exposed in the media before and during the Games, which contributes to their consolidation in the population's imagination), which reinforce already existing structures, and also to revitalize old spaces that were decadent in the city (Soares, 2013).

The holding of a major sporting event such as the Rio 2016 Olympic and Paralympic Games is an opportunity to accelerate urban regeneration projects and provide better conditions for infrastructure, safety, access to basic services and accessibility for the population of a large city.

The Olympic and Paralympic Games in Barcelona in 1992 are a positive example to be followed by other host cities. The city stands out for taking advantage of the Games to overcome the stagnation of the 1980s, to modernize and leap ahead, becoming a cosmopolitan city, very well evaluated according to contemporary patterns of urban development. Most of the investment was made in the urban infrastructure itself (especially in the area of transport), integrating the historical centre with the coast and leaving to the population of the city a legacy much larger than the sports legacy (Mascarenhas, 2008).

Another example is highlighted by Proni (2010), Beijing city in China, was host city of the 2008 Olympic and Paralympic Games. According to the author, were the most expensive Games in history, the Chinese government invested in urban regeneration and modernization, benefiting the population of the metropolis. There was an expansion of the road network: highways, bus lines, subways and urban trains. In addition, the city has won a new international airport.

At the London Olympics in 2012 the development of the Olympic Park would be used as a catalyst for the revitalization of the Lower Lee Valley region in the district of Stratford, a region forgotten after World War II, 
when it was subjected to major bombardments that left buildings and abandoned warehouses. This region has become an area with diverse socioeconomic problems, nationalities and religions, with low educational level and high unemployment (Johnson \& Aguiar, 2016).

Significant investment and infrastructure development in and around the Olympic Park accelerated the process of regenerating East London that had been going on for 30 years, from the development of London's Docklands in the 1980s to the Olympic Park after the Olympics. Games, now renamed Queen Elizabeth Olympic Park, and becoming the largest park to be built in Europe in over 150 years (Greater London Authority, 2012).

These positive examples of host cities that took advantage of the opportunity, through mega-sports events, to promote the urban regeneration of the city served as inspiration for the process of urban regeneration planned for Rio de Janeiro.

The main area thought for urban regeneration for the city, the port area of Rio de Janeiro, composed of the neighbourhoods of Saúde, Gamboa, Santo Cristo, Caju and parts of the Centre, correspond to 490 hectares (about five million square meters). According to the IBGE 2010 census, there are more than 48 thousand inhabitants arranged by the Conceição, Saúde, Pinto, Gamboa and Providência (IBGE, 2012) hills. This region was underutilized during the 1980s with the change of activities to the Port of Itaguaí, which generated a process of physical and social degradation (Toledo, 2012). These areas have idle and abandoned spaces. In the past, industrial and commercial activities, often aggressive to the environment, have been developed as a result of extensive exploitation and use of the soil and natural resources (Marker, 2003).

Cabernet (2006) defines these areas as brownfield, considered as terrain or environment affected by its previous, abandoned or underestimated use, located in a developed urban area that may be suspected or confirmed to be contaminated, requiring interventions to be reused and beneficial use.

Preuss and Ferber (2008) use and occupy the land is a cyclical process where degraded areas will exist and even when some are revitalized, receiving a new use, others in different parts, will lose their use and will be abandoned.

The port is closely related to the economic, social and cultural development of the country, in particular with the commercial activities of import and export of goods. To speak in the Port of Rio de Janeiro is to relate this history of construction and expansion of the port mainly to the coffee cycle, but also to architectural projects, engineering, tourism, urban planning (Pinheiro \& Rabha, 2004).

The urban operation Maravilha Port, a set of interventions coordinated by the Municipality of Rio de Janeiro with the support of the State and Federal and State Government, aimed to create new conditions of work, housing, transportation, culture and leisure for the resident population prioritizing the economic development of port region (Prefeitura da Cidade do Rio de Janeiro, 2011).

The City of Rio de Janeiro created the Urban Development Company of the Region of Rio de Janeiro Port (CDURP), instituted by Complementary Law 102/2011, to manage and oversee the revitalization. The Porto Novo Concessionaire was contracted through a public bidding process to carry out the works and provide municipal public services until 2026, in the largest public-private partnership in the country. Contracted works include the construction and renovation of urban infrastructure networks (water, sanitation, drainage, energy, public lighting, natural gas and telecommunications), demolition of the 4,790 meters of Elevado da Perimetral 
and replacement of the current road system by a new concept of urban mobility that implements new roads, with emphasis on Highway and Binary of Porto, implantation of the Light Rail Vehicle (VLT) with a $28 \mathrm{~km}$ network with connections between different modalities (ferries, subway, train, bus and Bus Rapid Transport (BRT) Transbrasil) and local (bus station, airport, cable car, $17 \mathrm{~km}$ on bike paths and large pedestrian areas (Porto Maravilha, 2017).

\section{Social Legacy and Deodoro X-Park: Whitewater Stadium}

In this study, sporting legacy is understood as the tangible and intangible results that can be identified and measured and that are created by and for the accomplishment of a sporting event remaining throughout the event and post-event (Kaplanidou \& Karadakis, 2010). For Sant and Mason (2015) the tangible legacies are those that can be more easily identified and measured (sports and transport structures). According to the authors, the intangible legacies (value of the event for the community and the improvement of the image of the country as host) are more subjective indicators, but no less possible to evaluate.

Chappelet (2012) associate the social legacy of a mega-sport event with the symbolic nature of residents' perception of experience and direct or indirect involvement in the event. Thus, an essential part of the social legacy of the mega-event is the change in the residents' perception of the host city or region. To better understand the social legacy, Clark, Kearns and Cleland (2016) point out that the impact on communities must be considered as a process, and therefore, they point to three distinct and complementary moments for the evaluation of these impacts.

The first moment, pre-event, comprises the decision-making phase on the regeneration of associated areas, with displacements, demolitions and constructions of new infrastructures. According to the authors, the community is usually in opposition to the planning developed, because the investment made by the big corporations and, the lack of the democratic participation. Community involvement can be a "risk factor", interfering with the delivery of the project. This context may cause the "host community" at the time of the event to be different from the existing community in the pre-event phase.

The second moment, reported by Clark, Kearns and Cleland (2016) is the moment of the event, in this, a set of behaviours and processes are considered (safety concerns, cleaning) in order to enhance a good image of the city for tourists and spectators of the event, culminating in changes in the routine and dynamic in the community.

Finally, in the post-event period, the host community may have the perception that the promised legacy is directed toward wealthier and non-resident people. In addition, facilities appropriate for a sporting event, but not continuously sustainable, are another risk factor for the legacy of the mega-event to the community (Gold \& Gold, 2011). There is also the possibility that restructured sites can only be used by more influential citizens and not be financially accessible to the community at large (Clark \& Kearns, 2015, Clark et al., 2016).

According to Greene (2003), the guarantee of fundamental rights can be achieved through the creation of programs linking the event to the needs of the population, so that the profits generated by the events are brought back to the communities, such as employment, income, security, education, mobility, urban development, social promotion through policies for democratization to access to sports and leisure, which can be felt by the population before, during and post event.

Preuss (2007) states that social legacies can also be negative such as a) the transformation of public spaces into private spaces; b) the displacement of the poorest populations caused by the works and constructions 
related to the mega event; $c$ ) the ennoblement of certain regions of the city, which makes the less fortunate that live in these regions do not rely on their place of residence.

Corroborating the previous statements, it was observed that many social legacies were developed in the ante and during the games, as highlighted in the study presented by the FGV on the impact of the Rio 2016 Olympic Games on the life of the population of Rio de Janeiro. There was improvement in several social indicators of the city, comparing data from the period before the announcement of the choice of the host city with the current moment, with progress in 36 indicators of the 38 evaluated (FGV Social, 2016). However, past the games, we are witnessing the emergence of negative legacies, which can be direct or indirect results produced by the Rio 2016 games.

One of the main cases of social legacy in the Olympic city was the Deodoro X-Park Whitewater Stadium. Despite Rio de Janeiro Mayor told to be against the construction of the Whitewater stadium, Deodoro X-Park brought to the region improvements in urban infrastructure and social area. This area has received a lot of improvements, mainly in infrastructure working as an accelerator for local development, regenerating a degraded area. The venue has received improvements in the neighbourhood, open new streets, put pavement and, promoting the renovation of Ricardo de Albuquerque train station, improving and creating accessibility in that area.

The stadium was delivered in November 2016 to the International Challenge Aquece Rio of Slalom Canoeing, a test event for the Olympic Games. Composed of 2 artificial waterways, the main one destined to the official competitions, has 242 meters of extension and descent of 4.5 meters between the start and the arrival, and has its rapids formed by the volume of $12 \mathrm{~m} / \mathrm{sec}$. The secondary, 200 meters long and approximately 2 meters of unevenness, operates with the estimated volume of $10 \mathrm{~m}^{3} / \mathrm{sec}$, providing a specific area for warm up, supplementary training and release of the athletes after the competitions.

In December of 2015, the warm up lake was opened to the population (mainly those coming from Deodoro, Ricardo de Albuquerque, Anchieta and adjacencies). With all the infrastructure set up by the city hall (with a support structure, with feeding points and bathrooms / locker rooms for use), it proved to be an anticipated legacy. Between March and September 2016, space was again managed by the Organizing Committee, returning to the legacy mode in September, when it was reopened to the population (Santos Neto et al., 2016; Terezani, 2017). After the Games, APO (2016) stated the desired legacy was the recreational use in the warm up lake sharing the space with grassroots and the high-performance athletes, corroborating the legacy planned in the bid phase (CO-RIO, 2009).

Eduardo Paes, then mayor of the city of Rio de Janeiro, translating his enthusiasm with the repercussion of the sports equipment said that X-Park "is like a beach that serves a very abandoned area of the city ... is a paid equipment with federal resources for the Olympics, but it becomes a municipal space and the city will pay for it" (Brasil, 2015). Like the expected use of this equipment, the APO (2016, p.125) stresses that "social aspects related to sports facilities refer to the post-game use they provide, both from a sports point of view and from public services arising from the characteristic of constituting themselves in reference public equipment in their territorial base ". 


\section{CLUSTERS}

\section{Deodoro Olympic Park}

The Deodoro Sports Complex begins to take shape for the 2007 Pan American Games. With an area of high population concentration and many young people, Deodoro received a massive investment for Rio 2007, as it is a priority place for the social reform in the city of Rio de Janeiro. Built in an area belonging to the Brazilian Army, sports facilities were planned within the Olympic standard, serving as a strategy for the Olympic bid to host the 2016 Games (CO-RIO, 2007). These facilities were subsequently used at the Military World Games in 2011.

By 2016, upgrading existing sports facilities, the Deodoro Olympic Complex emerges, which has become the second largest sports complex in the Games. Divided by the extensive Brazil Avenue are the North and its respective zones $\mathrm{A}$ and $\mathrm{B}$. "Zone $\mathrm{A}$ " houses the Radical Park, which includes the Slalom Canoe, the BMX track and the $4,850 \mathrm{~m}$ mountain bike course.

The Zone B consists of the Youth Arena (Women's Basketball, Fencing, Modern Pentathlon, Wheelchair Fencing), National Shooting Center (Olympic and Paralympic Sports Shooting), Deodoro Aquatic Center (Modern Pentathlon), Stadium of Deodoro (Rugby 7 and Modern Pentathlon - Both Olympic and 7-Paralympic Football) and Olympic Grass Hockey Center.

The South sector concentrates the "Zone C" and congregates the Olympic Centre of Equestrian (Salto, Dressage and Complete Riding Contest), formed by the Cross-Country Circuit, Central Arena, Handlers' Village, Veterinary Clinic and, other spaces dedicated to Equestrian services.

The "Zona A" was contemplated with an urbanization plan in the surroundings of the X-Park through a program known as "Bairro Maravilha", as asphaltic paving; sidewalk paving, accessibility ramps. In the area covered by the Complex (Zones B and C), and along with the intervention in Military Village road system, the infrastructure of public services (sanitation, natural gas and electric energy) was implemented. Within the planning for mobility, the region received the Trans-Olympic, via which connects Barra da Tijuca to Brazil Avenue, along with the BRT corridor, providing a greater integration between the modalities with the local population. In the railway system, there was a modernization in the stations of Deodoro, Military Village, Magalhães Bastos and Ricardo de Albuquerque (APO, 2016).

The Post Games is marked by a division in the management of these facilities. While the permanent equipment of "Zones B and C" was under the responsibility of the Brazilian Army through the recently created Sport Detachment of the Military Village (DDVM), the X-Park, located in an area jurisdiction of the Brazilian Army (EB), was leased to the City Hall of the City of Rio de Janeiro aiming at the Olympic Games. With a projected cost of BRL\$ 13.42 million for the year 2017 and, with the political-economic scenario going through changes, the projected use for space was below the planned potential.

The park was reopened in September 2017. The delay, according to Rangel (2017) was due to the understanding of the operational management of the equipment by the managers of the City. The same reporting continues and informs that the operation to reactivate the swimming pool will not empty the lake, thus opting for the application of chemicals and the use of specialized machines. According to information from the undersecretary herself, the former municipal administration (2013-2016) disbursed BRL \$5.8 million in the last three months of last year to operate the park, but the current management intends to manage it 
with BRL\$ 10 million per year, in addition to offering sports schools for canoeing, skateboarding, BMX, and beach volleyball.

To this end, the management will be shared between the Brazilian Confederation of Canoeing (CBCa), which will be responsible for the coordination of the nautical sports activities, the BMX practice will be with the Brazilian Cycling Confederation, while the cleaning, maintenance and monthly cost will be destined to the City Hall of Rio de Janeiro (Confederação Brasileira de Canoagem, 2017). Moreover, managers have an expectation of use by six thousand people / day in the installation.

\section{Barra Olympic Park}

The land where the Olympic Park of Barra is located dates back to the first race track in the Rio de Janeiro city, then State of Guanabara: the racecourse New Caledonia, inaugurated on July 10, 1966 and belonged to Caledônia Predial Ltda. After selling three thousand cabins and chairs, the race track was expropriated in 1973, without ever delivering the product to buyers. However, in 1971, therefore, in a period prior to expropriation, the construction of the race track city of Rio de Janeiro began, in the Baixada de Jacarepaguá. For the adaptation to the new project, it was necessary the landfill of the Peninsula of Itapeba. ("Autódromo carioca terá o circuito invertido, 1974; "Obras do autódromo de Jacarepaguá devem ser aceleradas", 1975).

In the 1990s, the race track returned to prominence on the world stage. In 1995, contracts were signed with the International Motorcycle Federation and Intag, a Brazilian promoter with CART, organizer of Formula Indy (GP de moto: contrato para a prova do Rio é assinada, 1995; Rio está no calendário da F-Indy em 96, 1995; Aguiar, 1995). The investment was estimated at BRL $\$ 25$ million with the reforms of the race track. Around 1,500 direct and indirect jobs were generated in the reform of the race track for these events (Nogueira \& Barreto, 1995). In 2005, with the delay in signing the contract and the refusal of the Municipality to transfer US\$ 3 million to Dorna, holder of the organizing rights of the event, there was an end point in the realization of the world motorcycling championship in Rio de Janeiro, having as official reason the schedule of the works for the Pan American Games (Nogueira, 2005).

Pan and Para Pan American Games (2007) were the initial mark of this coalition in favour of urban development in the city. The urban mobility envisaged in the application bid contemplated the modernization and opening of new roads in the capital and in the metropolitan region, the expansion of the subway and the modernization of the train system. However, some of the interventions were not carried out, privileging those planned for the surroundings of the competition venues, and what was seen were actions focused on planning related to traffic and public transportation during the games. Priority was given to actions aimed at the participants of the competition, such as exclusive circulation lanes between accommodation, training and competition venues, in order to make it easier for them to travel. For the public, reinforcement was planned in the bus lines destined to the places of competition, besides the lines of the Pan, special lines that came into service during the period of the games, as well as the extension of the hours of operation of the subway. It was observed the concentration of the interventions in Barra da Tijuca, with actions focused on infrastructure and urban planning around Vila do Pan to Riocentro (Brasil, 2007; CO-RIO, 2007).

In the space of the racetrack, the Sports Complex Sports City was built, with the allocation of the Maria Lenk Water Park, the Rio Olympic Arena and the Velodrome, altering the layout of the circuit, being possible, from then on, only to receive national competitions of motoring at the same time, Nogueira and Magalhães (2005) report that the space will receive a Stadium, a four-star hotel and commercial buildings after the event. 
Magalhães (2011) reports the launch of the announcement for the international competition for the Master Plan of the Olympic Park in Barra. The Ministry of Sport described the possibility of evaluating the indication of the City Hall by a Public-Private Partnership (PPP), seeking to attract investments to the unused areas (the equipment would occupy $40 \%$ of the space allocated to the Park), thus helping maintenance and urbanization of space.

Seven new sports facilities were planned for the space that already had the Sports Complex Sports City (Rio Olympic Arena, Olympic Velodrome River, Maria Lenk Aquatic Center). 1) Carioca Arena 1: basketball, wheelchair basketball and wheelchair rugby; 2) Carioca Arena 2: wrestling, judo and boccia; 3) Carioca Arena 3: fencing, taekwondo, paralympic judo and paralympic fencing; 4) Future Arena: handball and goalball; 5) Olympic Aquatics Stadium: swimming, water polo play-offs and paralympic swimming; 6) Olympic Tennis Center: tennis, wheelchair tennis and 5-a-side football; 7) Olympic Velodrome River: track cycling.

As described in the application bid, the heart of the Games was in the neighbourhood of Barra da Tijuca, reported as a fast-growing region that would have a legacy planned for the new sports facilities and connectivity through a new road system and transport hubs (CO-RIO, 2009).

Unlike in the planning for the Pan American Games, the intervention for the Games involved works on the Barra da Tijuca road system, with duplication of the main avenues (Americas, Abelardo Bueno and Salvador Allende), the opening of the Grota Funda Tunnel; the creation of the Bus Rapid Transit corridors (BRT Transoeste, BRT Transcarioca and BRT Transolímpica) and three terminals (Recreio, Olympic Center and Alvorada); the subway line 4 (Botafogo - Jardim Oceânico). All this transformation allowed Barra da Tijuca to connect the north, south and downtown areas by integrating different modalities of transportation (bus, train and subway) and shortening distances between the different regions and neighbourhoods with the modernization of the system local road.

In August and September 2016, the Olympic and Paralympic Games were held. After seven years of intense changes, the sense of belonging of the space returned to the residents and visitors of this new urban centre in the capital of Rio de Janeiro. As described by the APO (2016, p.47), "the transformation from the period of the Games to the legacy period provides for land and urban changes. As a result, $60 \%$ of the total area will remain as public area, $38 \%$ being free areas and $22 \%$ as permanent arenas. "This transformation will take place in the medium term, being fully delivered as the retrofits are carried out. The space has been used for the accomplishment of events, but without being totally established according to the planning of the legacy way. For the neighbourhood, another area of community interaction was established, integrated with the other regions of the city through public transport, as happened with the city of Barcelona and Beijing, with the investment in urban infrastructure, creating a kind of Olympic belt in the city, reducing distances and connecting regions.

\section{Maracanã}

The construction of the Journalist Mário Filho Stadium, Maracanã in Rio de Janeiro was only started in 1948 and was completed in 1950 with the goal of hosting the 1950 World Cup in Brazil. That year, the stadium received 200,000 spectators in the final match of the World Cup between Brazil and Uruguay. The world title lost by Brazilians still reverberates in the history of world football (Carvalho, 2008).

There are probably rare sports structures in the world that have gained prominence in comparatively short period of their existence, such as Maracanã. Football fans from all over the world associate great moments 
of the sport (especially soccer) with the name Maracanã, the "Sacred Temple in the country of football" (Goopert, Stockhusen, \& Moschner, 2014).

The first major renovation of Maracanã took place in 2005 and 2006 as the city of Rio de Janeiro hosted the XV Pan American Games in 2007. Reconstruction of the stadium was made to comply with the determinations of the Fédération Internationale de Football Association (FIFA). The Maracanã was the scene of the opening and closing of the Games and the final of women's football. At a total cost of BRL $\$ 304$ million, two other facilities were renovated together at the stadium, Maracanãzinho and Julio Delamare Water Park.

The Pan American Games in 2007 provided evidence that the country could hold other mega-sport events. That same year, Brazil was chosen to host the Soccer World Cup in 2014. The Maracanã Stadium received the FIFA World Cup again in 2014. As a result, it was required to reform some Brazilian stadiums, the construction of others and, in general, the change in the experience of watching football due to the requirements for the competition sites made by FIFA (Chimento, 2016).

The so-called "FIFA standard" requires, for example, the installation of individual seats, lawn dimensions up to lawn maintenance recommendations and energy savings. In 2010, the Maracanã structural reform began, with the goal of modernizing the stadium for the 2014 World Cup and 2016 Olympic Games. In 2013, the renovation was completed, the new Maracanã won praise for comfort, modernity and security, and with deep modifications the stadium was fit to host the 2014 World Cup.

The decision to host the 2014 World Cup was not an isolated event. It occurred in a period very close to the bid of Rio de Janeiro city to host the XXXI Olympic Games in 2016 (Hollanda \& Medeiros, 2014).

Rio received the Olympic Games in 2016. The capital of Rio de Janeiro won the competition with Madrid, Tokyo and Chicago among the members of the International Olympic Committee (IOC) in the election in Copenhagen, Denmark. It was the first time that South America hosts the event. Thus, Brazil received the two biggest events of the world sport in a period of two years.

The Maracanã Cluster had five sporting venues that took the Games to the North Zone of the city: Maracanã, Maracanãzinho, Júlio de Lamare Water Park, João Havelange Olympic Stadium and Sambódromo (crib of Rio's samba). The legacies of the region include the expansion of the Sambódromo, completed in February 2012 (more than four years before the Games), improvements around the Maracanã Stadium and the João Havelange Olympic Stadium.

The expansion of the Sambódromo was a long-standing promise, it was an accelerated legacy of the Games. The parade stage of the samba schools during Rio carnival, the largest popular festival in the world, the Sambódromo was renovated and delivered in 2012. Restoring the original design made by the architect Oscar Niemeyer almost 30 years after the construction. By maintaining symmetry between the sets of supports on each side of the avenue, the facility's capacity increased from 60,000 to 72,500 seats through a partnership with the private sector. During the Rio 2016 Games, the Sambódromo received the beginning and end of the Marathon, as well as the Archery events. (Prefeitura da Cidade do Rio de Janeiro, 2016).

Considered the home of Brazilian volleyball, the Maracanãzinho was extensively remodeled for the 2007 Pan American Games, Maracanãzinho's total official capacity for the Rio 2016 Olympic Games was 11,400 seats for the Volleyball competition. 
The Julio de Lamare Water Park a major reform project was put into practice for the Rio 2016 Olympic Games. Disabled in 2013, the Júlio Delamare Water Park in the Maracanã Complex, north of Rio de Janeiro, has been renovated for the Olympic Games Rio 2016. The Rio 2016 Committee took over the renovation of the park and Maracanãzinho. The works, budgeted at about BRL\$ 40 million, were part of the Maracanã Cluster counterpart.

The João Havelange Olympic Stadium (Engenhão) received Athletics during the Games. The stadium was built for the Rio 2007 Pan American Games and had its capacity temporarily expanded from 45,000 to 60,000 spectators for the 2016 Olympic Games. In addition, the stadium environment has received urban interventions to facilitate urban mobility and accessibility of the population, such as standardization and conservation of sidewalks, creation of ramps and installation of tactile floor near the stadium.

\section{Copacabana}

When we talk about Rio de Janeiro, the name of Copacabana soon comes to our mind, a privileged place of natural beauty, which attracts millions of tourists, especially at the New Year's Eve party. Its beach is the most important point measuring approximately $4.5 \mathrm{~km}$, divided into 6 sections, each marked by a beach station (station). At the south end of the beach is a fortress (Fort of Copacabana), from where one has a great panorama on the whole coast of Copacabana. At the north end is Leme.

The Copacabana cluster comprised four sports facilities: i) Copacabana Stadium (temporary venue - beach volleyball); ii) Copacabana Fort (temporary venue - cycling road, open water marathon and triathlon - Olympic Games; parathathlon and marathon - Paralympic Games); iii) Rodrigo de Freitas Lagoon (permanent venue - rowing and canoeing - Olympic and Paralympic Games); iv) Marina da Gloria (permanent venue - sailing Olympic and Paralympic Games). Having as its main characteristic temporary facilities, Copacabana has historically referred us to beach volleyball competitions, as well as marathons, cycling and shows.

The Rowing Stadium, with a project dating back to 1954, was designed to be a Nautical Club. Only in 1974, eight garages were built, instead of the 14 originally designed. After a long abandonment of space, in 1997, the area was ceded to a group of investors. In 2005, with preparation for the Pan American Games, the historic facade of the stadium was imploded, under allegation that it was outside the parameters demanded by the Pan American Sports Organization (ODEPA). Thus, consequently, it was possible to adapt the space to the wishes of the investors, who finally managed to build a new grandstand that was shared with the construction of movie theatres for their entertainment space. Since 2007, rowing and canoeing at this stadium has been a differential for the city, since these competitions are usually played outside the Games. By 2016, adjustments were made for accessibility, the renovation of the control tower and the garage of the boats, as well as foreseen as legacy by the Organizing Committee, the construction of accommodation for the athletes (Urbe Carioca, 2016; CO-RIO, 2009).

The Marina in Glória, inaugurated in 1977, has traditionally been the setting for sailing competitions in the city of Rio de Janeiro. For 2007, the National Historical and Artistic Heritage Institute (IPHAN) have embargoed the works planned for the Pan American Games. In 2009, the space was granted to private initiative. The Rio 2016 Organizing Committee planned as a legacy for space, the development of a new area of competition. This planning was intended to provide a more modern infrastructure for sailing practitioners (CO-RIO, 2009).

After completing the competition, and analysing the Single Legacy Plan, a document devised by the Olympic Public Authority (APO), it is possible to infer that this cluster did not appropriate the Rio 2016 achievement 
to leverage sport or social legacy and that despite the modernization of spaces and of a supposed planning of legacy done by the Organizing Committee, the reality portrayed shows a functional scenario like the one of before the mega-events realized. In addition, due to the characteristics of temporary or already established leases, no urbanistic or mobility actions originated in the cluster were observed.

\section{CONCLUSIONS}

The scenario of transformations in the urban space of the city of Rio de Janeiro was intense between 2009 and 2016. However, these changes were more perceived in some areas to the detriment of others. The actions of urban regeneration were more forceful in the area of the Olympic Boulevard, provoking the revitalization of the area of Porto, returning the population an area "abandoned" in the centre of the city. The area of the Olympic Park of Barra went through a requalification, transforming what was a race track into an area with sports equipment, free circulation area and another area that will be occupied by private enterprises in the future. The Deodoro Olympic Park underwent a process of urbanization in Zone A and, concurrently, offered the local population a new leisure space (the X-Park) where once it was a military training area.

In this sense, the catalysing effect of the Olympic Games was observed in the Olympic Boulevard, opening the space facing the sea in the port area of Rio to the population, something similar to that observed in Barcelona 1992. However, if the analysis is done in conjunction with urban mobility, the changes were more consistent, with the opening or updating of new roads, shortening the distance between regions and reducing territorial segregation. The city's public transportation network changed considerably between 2009 and 2016, with greater integration between different modes and with the partial completion of line four of the subway, connecting the south to Barra da Tijuca. However, the rail system has invested in improvements only near to Deodoro and Maracanã clusters, with station upgrades putting them into modern accessibility standards.

Accessibility, which was one of the main sports legacies expected for Rio 2016, does not relate solely and exclusively to persons with disabilities, and it is expected that the Games will act as a catalyst throughout the territorial extension and not only in the surroundings of the sports facilities. Thus, through a long process of transformation in our society, where attitudes, behaviour and the change of perception towards people with disabilities, can become one of the legacies left by the Games, in expanding beyond the intended sites for the sports or cultural achievement of Rio 2016.

Finally, our analysis revealed that the social legacy was more apparent around Deodoro X-Park, where the local community was able to use the changes made through Rio 2016's urban and sports planning. In this case, leisure in an area not previously accessed by the population, public health service and access to a new public transport network, made this part of the Deodoro cluster the most benefited from the Rio 2016 Games. In daily life, benefits focused on the issue of urban mobility, with the updating of the road system (duplication of roads and asphaltic and signalling modernization, together with the opening of the Trans-Olympic) and the already mentioned expansion of the public transport network. As quoted by the specialist in Olympic Studies, Professor Lamartine DaCosta, the games promoted an integration of the regions of the city or the formation of a connected belt through the four Olympic clusters.

When the city is chosen to host the Olympic Games, a radical transformation is expected in a short space of time, not only in the modernization and construction of sports equipment, but also in those related to urban space such as regeneration or urban renewal, accessibility and urban mobility. In the case of the city of Rio de Janeiro, this catalytic effect became, mainly, results in the area of urban mobility and, with focus of action 
in the axis of the Games (works carried out around the competition sites) in the area of accessibility and regeneration / urban renewal. In the evaluation of the social legacy, those who were most able to enjoy the equipment made available to Rio 2016 were the residents surrounding of the X-Park, the second largest park in the city and located in an area with no systematized leisure option and the renovation of the port area, giving access to this forgotten part of the city. Future studies should measure and compare with other Olympic cities the interventions and the final costs for the holding of the Olympic Games, evaluating together with the speech before the benefits entailed by hosting a sports mega-event.

\section{REFERENCES}

Abreu, M. (1988) Evolução Urbana do Rio de Janeiro. Rio de Janeiro: Iplanrio/Jorge Zahar Editor.

Aguiar, J. E. (1995, June 11). Brasil terá, em março, prova em circuito oval. O Estado de São Paulo, p.E9.

Andreatta, V. (2006) Cidades quadradas, paraísos circulares. Os planos urbanísticos do Rio de Janeiro no século XIX. Rio de Janeiro: Mauad.

APO (2016). Planejamento de Uso do Legado. Rio de Janeiro. 2016.

Autódromo carioca terá o circuito invertido. (1974, July 12). O Globo, p.10.

Brasil (2007). Relatório sobre os XV Jogos Pan-Americanos e III Jogos Parapan-Americanos Rio 2007. Brasília: Governo Federal.

Brasil (2015, December 23). Legado antecipado: Parque Radical do Rio, em Deodoro, é aberto à população. Retrieved from: http://www.brasil2016.gov.br/pt-br/noticias/legado-antecipado-parqueradical-do-rio-em-deodoro-e-aberto-a-populacao

Burbank, M. J.; Andronovich, G.; \& Heying, C. H. (2002) Mega-events, urban development and public policy. The Review of Policy Research, 19(3), 179-202. https://doi.org/10.1111/j.15411338.2002.tb00301.x

Cabernet (2006). Sustainable Brownfield Regeneration: CABERNET Network Report. Nottingham: University of Nottingham.

Carvalho, P.A.M. (2008). Mário Filho, futebol e Maracanã. Monografia Graduação em Comunicação Social. Universidade Federal do Rio de Janeiro.

Chappelet, J. L. (2012). Mega sporting event legacies: a multifaceted concept. Papeles de Europa, 25, 76.

Chimento, M.R. (2016). A retórica da perda e a questão do patrimônio no futebol padrão Fifa: o caso do Maracanã. Geosaberes, 7(12), 104-118.

Clark, J., \& Kearns, A. (2015). Pathways to a physical activity legacy: Assessing the regeneration potential of multi-sport events using a prospective approach. Local Economy, 30(8), 888-909. https://doi.org/10.1177/0269094215601993

Clark, J., Kearns, A., \& Cleland, C. (2016). Spatial scale, time and process in mega-events: The complexity of host community perspectives on neighbourhood change. Cities, 53, 87-97. https://doi.org/10.1016/j.cities.2016.01.012

Coaffee, J. (2011) Urban regeneration and renewal. In: Gold, J.R. and Gold, M.M. (ed.) Olympic cities: city agendas, planning, and the World's Games 1896-2016 (pp.180-193). London, Routledge.

CO-RIO (2007). Relatório Oficial XV Jogos Pan-Americanos e III Jogos Parapan-Americanos Rio 2007. 2 Vol.

CO-RIO (2009). Candidature file for Rio de Janeiro to host the 2016 Olympic and Paralympic Games. Rio de Janeiro: Bid Commission Rio 2016.

Confederação Brasileira de Canoagem (2017, September 22). Legado olímpico é reaberto depois de nove meses. Retrieved from: 
http://www.canoagem.org.br/imprensa/noticia/titulo/legado_olimpico_e_reaberto_depois_de_nove_ meses/paginas id/166/noticias id/3124.

FGV Social (2016). Mudança Social Carioca 2009-2016: o legado pré-olímpico. Retrieved from: http://www.fgv.br/fgvsocial/rio2016

GP de moto: Contrato para a prova do Rio é assinado. (1995, January 12). O Globo, p. 35.

Gold J. R., \& Gold M. M. (2011) From a to b: The summer Olympics 1896-2008. In: Gold, J. R, Gold, M. M. (eds) Olympic Cities 1896-2016, 2nd ed. (pp. 17-54). London: Routledge.

Goppert, K., Stockhusen, K., \& Moschner, T. (2014). Estádio Jornalista Mário Filho, Rio de Janeiro. Stahlbau, 83, 368-375. https://doi.org/10.1002/stab.201410163

Greater London Authority. (2012). Leaving a transport legacy 2012. Retrieved from: http://www.london.gov.uk/sites/default/files/leaving-a-transport-legacy.pdf

Greene, S. J. (2003). Staged cities: Mega-events, slum clearance, and global capital. Yale Hum. Rts. \& Dev. 6, 161.

Heere, B., Walker, M., Heather, G., Thapa, B., Geldenhuys, S., \& Coetzee, W. (2013). The power of sport to unite a nation: The social value of the 2010 FIFA World Cup in South Africa. European Sport Management Quarterly, 13(4), 450-471. https://doi.org/10.1080/16184742.2013.809136

Hollanda, B.B., \& Medeiros, J. (2014). Do 'Colosso do 'Derby' a 'Arena do Maracanã': a cidade, o estádio e as percepções dos torcedores de futebol sobre a Copa do Mundo 2014. Interseções: Revista de Estudos Interdisciplinares, 16(2), 328-353. https://doi.org/10.12957/irei.2014.16594

IBGE (2012). Censo demográfico 2010: características gerais da população, religião e pessoas com deficiência. Rio de Janeiro: IBGE, 1-215.

Johson, I., \& Aguiar, P. R. (2016). A Revitalização Urbana e a Infraestrutura de Transportes como Formas de Legado dos Jogos Rio 2016 ln: XIII Congresso Online - Administração. Retrieved from: http://www.convibra.com.br/upload/paper/2016/38/2016_38_13322.pdf

Kaplanidou K., Karadakis K. (2010). Understanding the Legacies of a Host Olympic City: The Case of the 2010 Vancouver Olympic Games. Sport Marketing Quarterly, 19(2), 110-117.

Magalhães, L. E. (2011, April 25). Parque Olímpico terá concurso internacional. O Globo, Rio, pp.16.

Marker, A. (2003). A reabilitação de áreas urbanas degradadas. Políticas, instrumentos e incentivos no cenário internacional. ProGAU: São Paulo, 2003. Retrieved from: www.prefeitura.sp.gov.br/arquivos/.../rel_marker_01_08_2003.doc

Mascarenhas, G. (2008). Barcelona 1992: um modelo em questão. In DaCosta, L., Corrêa, D., Rizzuti, E., Villano, B., Miragaya, A. Legados de megaeventos esportivos. Brasília: Ministério do Esporte.

Mello, J. O. B. (2012) A cidade, o urbanista e o plano. Um estudo para a Guanabara por Doxiadis. Monografia de especialização em Sociologia Urbana. Rio de Janiero: UERJ. Instituto de Filosofia e Ciências Humanas.

Moura, D., Guerra, I., Seixas, J., \& Freitas, M. J. A. (2006). Revitalização Urbana Contributos para a Definição de um Conceito Operativo. Cidades-Comunidades e Territórios. 12/13, 15-34.

Nogueira, C. (2005, February 18). Rio perde GP de moto. O Globo, p. 31.

Nogueira, C., \& Barreto, M. (1995, September 15). Festa para o motociclismo. O Globo, p. 32.

Nogueira, C., \& Magalhães, L. E. (2005, July 26). Acelera, autódromo. O Globo, Rio, p.13.

Obras do autódromo de Jacarepaguá devem ser aceleradas. (1975, January 28). O Globo, p. 16.

Pinheiro, A. I. F., \& Rabha, N. M. C. E. (2004). Porto do Rio de Janeiro: construindo a modernidade. Rio de Janeiro: Andrea Jakobsson Estúdio.

Porto Maravilha (2017). Porto Maravilha. Retrieved from: http://www.portomaravilha.com.br

Prefeitura da Cidade do Rio de Janeiro. (2011). Porto Maravilha. Retrieved from: http://www.portomaravilhario.com.br 
Prefeitura da Cidade do Rio de Janeiro. (2016). Rio 2016. Olympic and Legacy. Retrieved from: http://www.rio.ri.gov.br/dlstatic/10112/4379008/4129850/RIO2016_estudos_ING.pdf

Preuss, H. (2007). The conceptualisation and measurement of mega sport event legacies. Journal of sport \& tourism, 12(3-4), 207-228. https://doi.org/10.1080/14775080701736957

Preuss, T., \& Ferber, U. (2008). Circular land use management in cities and urban regions: a policy mix utilizing existing and newly conceived instruments to implement an innovative strategic and policy approach. Berlim: Deutsches Institut fuer Urbanistik.

Proni, M. W. (2010). Observações sobre os impactos econômicos esperados dos Jogos Olímpicos de 2016. Motrivivência, Florianópolis, 32-33, 49-70.

Rangel, S. (2017, August 06). Após Rio-2016, Parque Radical de Deodoro tem água suja e parada. Folha de São Paulo. Retrieved from: http://www1.folha.uol.com.br/esporte/2017/08/1907552-umanos-apos-abertura-das-olimpiadas-parque-radical-de-deodoro.shtml

Reis, A. C., Sousa-Mast, F. R., \& Gurgel, L. A. (2013). Rio 2016 and the sport participation legacies. Leisure Studies, 33(5) 437-453

Rezende, V. L. F. M. (2014) Planos, regulação urbanística e intervenções no Rio de Janeiro: diferenças entre pensar e produzir a cidade. III Encontro da Associação Nacional de Pesquisa e Pós-graduação em Arquitetura e Urbanismo. Arquitetura, cidade e projeto: uma construção coletiva. São Paulo.

Rio está no calendário da F-Indy em 96. (1995, June 11). O Globo, p. 63.

Roberts, P., \& Sykes, H. (2000). Urban regeneration: a handbook. Londres: Sage.

Rodrigues, A. E. M., \& Mello, J. O. B. (2015). As reformas urbanas na cidade do Rio de Janeiro: uma história de contrastes. Acervo, Rio de Janeiro, 28(1), 19-53.

Sant, S. L., \& Mason, D. S. (2015). Framing event legacy in a prospective host city: Managing Vancouver's Olympic bid. Journal of Sport Management, 29(1), 42-56. https://doi.org/10.1123/JSM.2013-0294

Santos, T., Correia, A., Biscaia, R., Araújo, C., Pedroso, C., Stinghen, F., ... Menezes, V. (2016). A qualidade da copa do mundo da FIFA Brasil 2014 nas cidades-sede. Movimento, 22(2), 611-624. https://doi.org/10.22456/1982-8918.57028

Santos Neto, S. C., Nóbrega, L. F. M., Dacosta, L. P., Haiachi, M. C., \& Terezani, D. R. (2016). Legado esportivo e social Rio 2016: o estádio Olímpico de canoagem slalom. III Fórum Científico EsEFEx.

Soares, P. R. R. (2013). Megaeventos esportivos e o urbano: a copa do mundo de 2014 e seus impactos nas cidades brasileiras. Revista FSA, 10(4), 195-214. https://doi.org/10.12819/2013.10.4.11

Taks, M., Chalip, L., \& Gree, C. (2015). Impacts and strategic outcomes from non-mega sport events for local communities. European Sport Management Quarterly, 15(1), 1-6. https://doi.org/10.1080/16184742.2014.995116

Terezani, D. R. (2017) Das corredeiras do estádio Olímpico de canoagem slalom ao conjunto aquático do Parque Radical: as conquistas e os desafios do complexo esportivo de Deodoro, a segunda maior área de lazer da cidade do Rio de Janeiro. In: Oliveira, A.F.S.; Haiachi, M.C. (Org.). IV Ciclo de Debates em Estudos Olímpicos - Diferentes olhares sobre os Jogos Olímpicos e Paralímpicos Rio 2016: a mídia, os profissionais, os voluntários e os espectadores. 1ed. São Cristóvão: Editora UFS.

Toledo, M. P. (2012). Participação de instituições locais em projetos de revitalização urbana: o caso do Projeto Porto Maravilha na cidade do Rio de Janeiro. Dissertação de Mestrado, Escola Brasileira de Administração Pública e de Empresas, Fundação Getúlio Vargas. Rio de Janeiro.

Urbe Carioca (2016, April 14). O "não-legado" do Estádio de Remo da Lagoa Rodrigo de Freitas. Retrieved from http://urbecarioca.com.br/2016/04/o-nao-legado-do-estadio-de-remo-da-lagoarodrigo-de-freitas.html

Yin, R. (2015). Estudo de caso. Planejamento e métodos. Porto Alegre: Bookman. 
